\title{
Review and Prioritize the Factors Affecting on Attract and Keep Audiences on the Internet at the Student Sports Organizations
}

\author{
Hasanzadeh.M. ${ }^{*}$, Amirhesari .S. \\ Islamic Azad University Central Tehran Branch, Iran
}

Copyright $@ 2015$ Horizon Research Publishing All rights reserved.

\begin{abstract}
The most important concern every marketing mental sport to find the audience and finally preserving and creating loyalty in sports audience discussion is attracting and keeping viewers and users by presenting electronic services through web sites. One method of establishing relations with the audience and most important priorities student sports organizations are considered. Web sites effectiveness student sports organizations in order to establish relations with the students and addresses are very important. Undoubtedly the situation of sport organizations has been changed all over the world, especially in Iran. In fact internet and E-commerce has become a tool for sport organizations to attract and keep the audience, also to communicate with fans and sport students. Therefore student sports organizations need to know the information in connection with their website which makes it able to their effectiveness and capability in communications and information and selling electronic services to evaluate. The aim of this investigation and identification of variables effective on the Internet services provided by Iran Student sports organizations .Given the necessary investigation of audiences student sports organizations active in Iran that electronic services through web site. Estimate by a questionnaire made based on a scale 5 option likert narrative that after you and the problem behaviors ankle bracelet polls model with the volume of 140 people had not have an accident in a separate distribution and has been collected. Method analysis test for this research, our analysis and Variance Friedman's and to study the connection between the investigation of variables test excluded solidarity and manuscripts diagnosing analysis has been used based on the results of the site users graphic variables, the contents site, ability, technical variables and reviewing the site purchases of Internet services web sites by the other conversional technical and other function" there was a meaningful relationship. Also the research priority each of the function" to attract audiences and keep respectively following has specified: reliability, technical varier, site investigations, and the façade site content site.
\end{abstract}

Keywords E-commerce, Interface Site, Navigation Site, Reliability Variable

\section{Introduction}

Communications can be exchange of information and association also knew about the transfer of information act will be the sender to receiver in a way that information is understandable (1). Each sports organization with 4 of the audience that sports organizations in each of the audience special duties for each audience are: present audience, last audience, future audience, rival audience. Constant communication and mutual through the web site is one of the duties of sports marketers in every four groups-audience (3). Electronic trade provides the possibility that the audience can get in touch with sport organizations in any part of the world through the website.( Representative11). Web site can be considered platform that in order to establish communication with customers and audience and facilitate interactions used to. Studies of Faster(1999) reveals that poor web site design result in losing numbers of customer and it is because of the customers' ability to find out what do they want. Also Kanlif(2000) mentioned that poor design could lose $40 \%$ of web sites reviews which is one of the negative experience of users and audiences. Customers addresses and Web sites that yield positive interaction with the web site by sports organizations do not believe that may find it easier physical presence of electronic communication $(6,8)$. The sport provides an unique features that one of them is intangibility, is being separation, Conversional, is being stored and unpredictable. All aspects and the process can be sports services with internet and technology web Esperanca do $(2,3)$, therefore electronic trade method is based on that information, products and services from the network of communications Computer bought and sold (5).Trade In electronic addresses can be without any cost to the site sports organizations refer to students' and enough information, 
news and needed services offered, and with other Web sites Representative compared the better choice to the audience gives sports $(13,3)$.

\section{Methodology}

\section{a) Method of research}

Investigation of the type you padding, in which the questionnaire for collecting information has been used. Researchers with surveys of addresses and Web sites users offices of physical education Research and Technology Ministry, Islamic Azad University, Payame Nour, the Ministry of Health, treatment and medical education and sports federation students' understand factors and variables Important in attracting users which have been?

In other words in cross-sectional this question is that the audience and users view offices of the Physical Education Public and private universities which factors attract audiences and keep receiving services and Internet web site are effective? Researchers with resources study books and articles related to the investigation and based on research and the effective factors in assessment sports Web sites in the form of group 5 factors site facade, site investigations, the content site, reliability and technical site after they were identified and their questionnaire made based on a scale five times likert with 25 question was designed and after narrative questionnaire experienced by university professors coefficient ankle bracelet each of you devise also criticized the coefficient Cronbach's was confirmed in final questionnaire with 25 questions prepared and ready for research. The questionnaire consists of two public information and the major section contains questions questionnaire in 5 Conversional and Conversional included 5 it was a question.

\section{b) Statistical methods}

In this investigation in order to test theories related to the framework has been evaluated factors and Internet services and celebrations analysis of the investigation of t- test for our analysis and Variance Friedman's and to study the connection between the investigation of variables test excluded solidarity and manuscripts diagnosing analysis has been used.

\section{Results}

The results of this study showed that $65 \%$ of statistical sample were men and $35 \%$ women. $17 / 9 \%$ of the society were under study and associate diploma and 58/6\% bachelor's degree and 23/5\% master's degree.

$32 / 9 \%$ of the society statistics between 18 to 25 years and are $26 / 6 \% 43$ to 34 years of age and the rest are more than 35 years of age.
Table 1. Educational characteristics

\begin{tabular}{|c|c|c|c|}
\hline Row & Group & Many & Percent \\
\hline 1 & $\begin{array}{c}\text { high school diploma and } \\
\text { diploma above }\end{array}$ & 25 & $17 / 9 \%$ \\
\hline 2 & Expert & 82 & $18 / 6 \%$ \\
\hline 3 & $\begin{array}{c}\text { Perfect } \\
\text { Expert }\end{array}$ & 33 & $23 / 5 \%$ \\
\hline 4 & Ph.D & - & - \\
\hline
\end{tabular}

Table 2. Age characteristics

\begin{tabular}{|c|c|c|c|}
\hline Row & Group & Many & Percent \\
\hline 1 & $18-25$ years & 46 & $32 / 9 \%$ \\
\hline 2 & $34-26$ years & 61 & $42 / 6 \%$ \\
\hline 3 & Up of 35 years & 33 & $23 / 5 \%$ \\
\hline
\end{tabular}

The table 2 distribution models many research age based on research findings parameter trust to the site is the most important factor in attracting and keeping internet auidences. Time to receive information services and sports audiences is the most important factor in parameter reliability to the site. Simplicity and transparency process for the purchase order, proper relation after receiving Audience services, having all kinds of various methods for receiving information and services and paying money, easy membership in the site and quick response to health" emails audiences were next priorities parameter confidence to the site.

The table 3 effective variables in attracting and keeping internet addresses and priority in their scale organizations students' sports audience suitable speed in the letter web pages (the appearance of the complete and rapid web pages) as the most important Variable Parameter in technical Varier have considered. Appropriate speed to access the database and also in a security system, being compatible with web pages different systems (with the system and various facilities) advice to the use of exaggerating vulnerabilities and suitable next priorities.

Optimum use of search engine domestic and foreign in the site, organizing and proper understanding of "Kiss me s, move easily between pages and returned to the main page, a site plan and the lack of, or at least having pages in construction parameters priority site investigations.

Based on the findings brief investigation and complete information in connection with the quality of services like technical information, the use, the price were the most important priorities of site content.

Having links with the audience, possible audience opinions and users in the site, complete information in connection with the organization, the quality of the ad site in were the next priorities Parameter site content.

Based on the findings priority research site facade parameters are brief and useful, as well as being suitable pages in different browser, the use of some international, color and the principles and graphical also brought use of multi Media. 
Table 3. Variables affecting the Internet to attract and retain audiences and prioritize them in sports, student organizations

\begin{tabular}{|c|c|c|c|c|c|}
\hline Row & variables & Components & Secondary variables & The average & $\begin{array}{c}\begin{array}{c}\text { Standard } \\
\text { deviatio } \\
n\end{array} \\
\end{array}$ \\
\hline 1 & $\begin{array}{l}\text { Variable } \\
\text { reliability }\end{array}$ & $\begin{array}{l}\text {-Information } \\
\text { stored in the } \\
\quad \text { audience } \\
\text { - Order Process } \\
\text {-Service }\end{array}$ & $\begin{array}{l}\text { Receive timely and complete information and services } \\
\text { Process simplicity and transparency of information } \\
\text { and services } \\
\text { Appropriate relationship with the audience after the } \\
\text { presentation of information and services } \\
\text { Alternative and different ways to get information and } \\
\text { services } \\
\text { Join the site easy and rapid response }\end{array}$ & $\begin{array}{l}4 / 46 \\
4 / 3 \\
4 / 23 \\
4 / 11 \\
3 / 96 \\
\end{array}$ & $\begin{array}{l}0 / 69 \\
0 / 82 \\
0 / 73 \\
0 / 88 \\
0 / 83\end{array}$ \\
\hline 2 & $\begin{array}{l}\text { Technical } \\
\text { variables }\end{array}$ & $\begin{array}{l}\text {-Speed } \\
\text {-security } \\
\text {-software and } \\
\text { database } \\
\text {-system design }\end{array}$ & $\begin{array}{l}\text { Using a secure system to receive } \\
\text { Web pages load faster } \\
\text { Appropriate speed access to database } \\
\text { Compatibility with different systems } \\
\text { Recommends the use of magnification and } \\
\text { appropriate to the user's browser }\end{array}$ & $\begin{array}{l}4 / 51 \\
4 / 36 \\
4 / 31 \\
3 / 88 \\
3 / 28\end{array}$ & $\begin{array}{l}0 / 7 \\
0 / 77 \\
0 / 77 \\
0 / 87 \\
1 / 1\end{array}$ \\
\hline 3 & $\begin{array}{c}\text { Variable site } \\
\text { navigation }\end{array}$ & $\begin{array}{l}\text {-logical structure } \\
\text {-easily } \\
\text {-Search Engine }\end{array}$ & $\begin{array}{l}\text { optimum use of search engine domestic and foreign } \\
\text { organizing a suitable site and understanding of "Kiss } \\
\text { me s } \\
\text { a move easily between pages and returned to the main } \\
\text { page } \\
\text { Suitable Site Map } \\
\text { Pages in the absence or lack of repair }\end{array}$ & $\begin{array}{l}4 / 22 \\
4 / 2 \\
4 / 19 \\
3 / 72 \\
3 / 6 \\
\end{array}$ & $\begin{array}{l}0 / 77 \\
0 / 73 \\
0 / 81 \\
1 / 04 \\
1 / 1 \\
\end{array}$ \\
\hline 4 & $\begin{array}{c}\text { Site contains } \\
\text { variable }\end{array}$ & $\begin{array}{c}\text {-information and } \\
\text { news } \\
\text {-information } \\
\text { services of the } \\
\text {-quality of } \\
\text { information } \\
\text {-interaction with } \\
\text { the audience }\end{array}$ & $\begin{array}{c}\text { Briefly and complete information in connection with } \\
\text { sports services } \\
\text { having links with online audience } \\
\text { opinions as possible audience on the site } \\
\text { complete information in connection with the } \\
\text { organization (Fax, mail telephone, , address. ) } \\
\text { The quality of advertising on the site }\end{array}$ & $\begin{array}{l}4 / 31 \\
4 / 12 \\
3 / 92 \\
3 / 9 \\
3 / 42 \\
\end{array}$ & $\begin{array}{l}0 / 77 \\
0 / 67 \\
0 / 88 \\
0 / 85 \\
0 / 98 \\
\end{array}$ \\
\hline 5 & $\begin{array}{l}\text { Interface of } \\
\text { site }\end{array}$ & $\begin{array}{c}\text {-graphic } \\
\text {-multi Media } \\
\text {-style and text } \\
\text {-flexibility }\end{array}$ & $\begin{array}{l}\text { The text is concise and useful } \\
\text { Suitability of the site in different browsers } \\
\text { International languages } \\
\text { color, Background and graphical } \\
\text { Effective use of multimedia and motion pictures }\end{array}$ & $\begin{array}{l}4 / 01 \\
3 / 85 \\
3 / 71 \\
3 / 55 \\
3 / 3\end{array}$ & $\begin{array}{c}0 / 74 \\
0 / 76 \\
0 / 91 \\
0 / 91 \\
1\end{array}$ \\
\hline
\end{tabular}




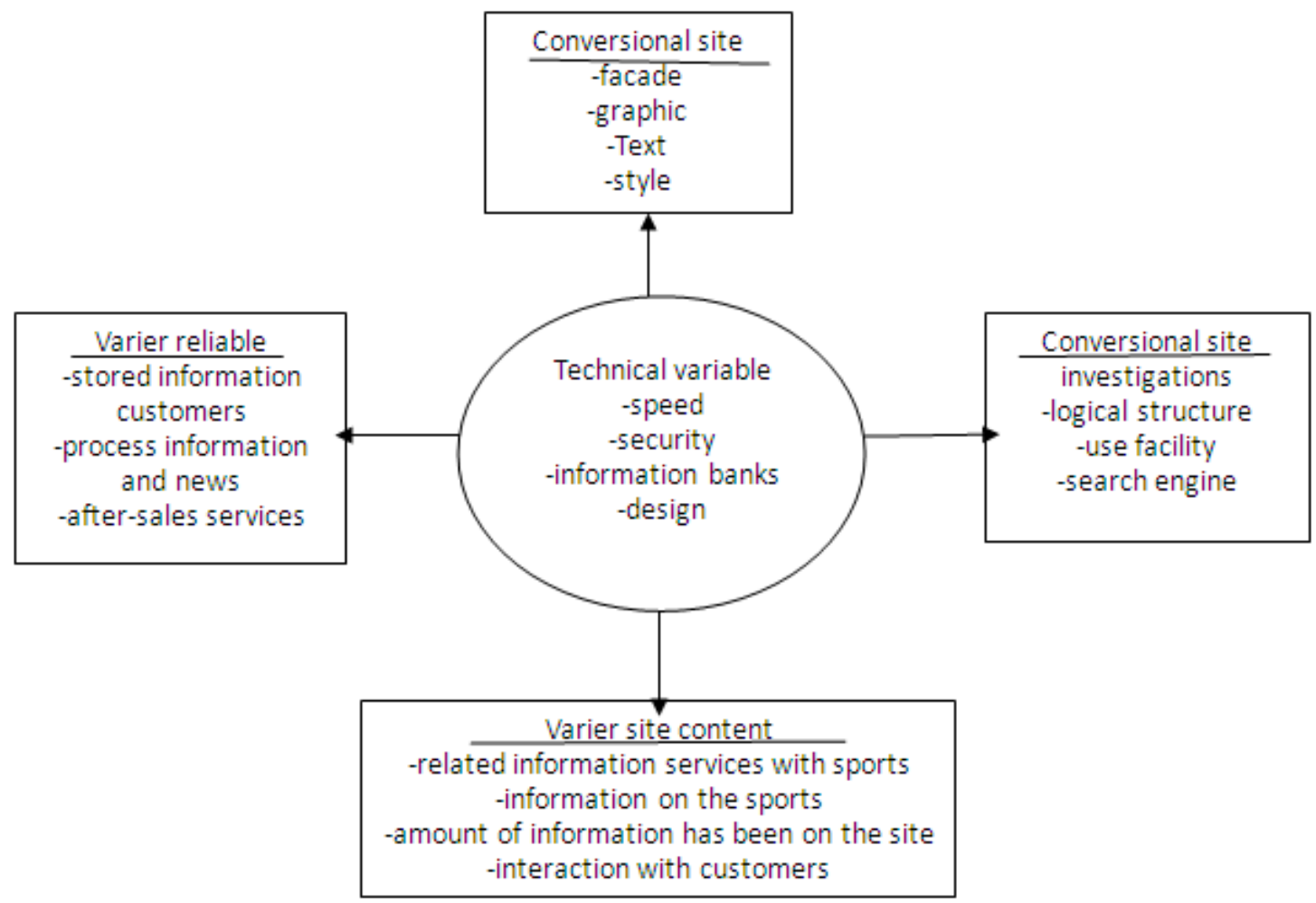

Figure 1. Conceptual model of technical variables on other variables influence

\section{Discussion and Conclusion}

The results of tests the theory of the research showed that the façade site variables, padding, content, reliability and technical variable in attracting and keeping audiences sports Web sites student organizations have positive effects.

The technical variables Impact to site navigation, site contains variable, Interface of site reliability Variable in attracting and keeping the audience organizations Web sites students' affect sports. Confirmation of this affect indicates that Conversional technical can improve the help of other variables, and a lack of attention or less attention to this point could attract or keep lead audiences.

In addition to the results, ranking relative five factors include:
1. reliability variable
2. technical variable
3. site navigation
4. site contains variable
5. interface of site

The highest priority of the audience view reliability to the site in services and attracts and protects them. And the lowest priority view of the audience is the façade site which indicates that this issue.

Audience progressing in sport organizations students' the lest attention to the façade site although technical variable can influence all other variable effectiveness.

\section{REFERENCES}

[1] Abels , E .G , White, M.D and Hahn , K . (1999) “ A user-based design process for web sites". OCLC Systems \& Services, Vol 15 No 1 pp 35-44

[2] Bolton,R.N Drew, j .H.(1991) A multistage model of customers assessments of service quality and value" journal of Consumer Research.(17):375-384

[3] Cunliff,D.(2000) “ Developing Usable web sites - A review and model, Internet Research : Electronic Networking Applications and Policy" Vol 1, No 4, pp 295-307

[4] Goldsmith, Mahmood., 1380, strategic models and strategies in Internet commerce, first published, Tehran, optimal publications

[5] Hasan Zada, mehrdad , .1386, global marketing, second edition, Tehran, researcher have arranged publications.

[6] Hassan Zadeh, MehrdadFa'al. , 1387 sports marketing, third edition, Tehran, researcher have arranged publications.

[7] Hassan Zadeh, MehrdadFa'al. , 1389 consumer behavior in sports and sports events, first published, Tehran, the publication s blue art.

[8] Hassan Zadeh, MehrdadFa'al. , 1390 organization and management, first published, Tehran, blue art publications.

[9] Jamal ,A. and Naser , K.(2002).”Customer satisfaction and retail banking :an assessment of some of the key antecedents of customer satisfaction in retail banking". International journal of Bank Marketing . (4):146-164

[10] Jenis. B. King.feel unhappy about. , 1382 marketing through 
Web translator Mohammad Ibrahim Jewelers nevertheless, Amir Kabir, Tehran's

[11] kanticks, Mike. , 1383, electronic trade, translators Ahmad Reza mensurable banker, Majid Abdul Baqee, first published, Isfahan, students Brienne publications.
[12] nikbakhshiTehrany, Mohammad Hassan Azar and Saaberi, Mehdi, 1380, familiarity with electronic trade and facilitating pitchfork, first published, Tehran, Iran ansito square.

[13] Turban, E . (2003) "Introduction to information Technology" Willy USA :112-124. 